\title{
Petter Nass
}

\section{Kritisk realisme og byplanforskning}

\section{Sammendrag}

Artikkelen drøfter vitenskapsteoretiske forutsetninger for at byplanlegging skal kunne vare mulig og meningsfull, og peker på kritisk realisme som en fruktbar vitenskapsteoretisk plattform for byplanforskning. Flere av dagens mest utbredte vitenskapsteoretiske posisjoner er uforenlige med å frambringe det kunnskapsgrunnlaget som er nфdvendig for at byplanlegging skal kunne spille en meningsfull rolle. Kritisk realisme anser tverrfaglig integrasjon som nфdvendig, mens konkurrerende posisjoner som f. eks. positivisme og poststrukturalisme neglisjerer og ekskluderer viktige deler av virkeligheten. Kritisk realisme anerkjenner både aktørers og strukturers selvstendige kausale påvirkningskrefter og gir dermed en god plattform for å unders $\phi$ ke årsakssammenhenger mellom samfunnsforhold, romlige bystrukturer og aktфrers (herunder planleggernes) handlinger. Kritisk realismes syn på hva slags forskningsbaserte forutsigelser som er mulige, passer med byplanleggingens kvalitative konsekvensvurderinger av losningsalternativer og forsiktige, konteksttilpassete anslag om effekters stфrrelsesorden.

Nøkkelord: Byplanlegging, kritisk realisme, tverrvitenskap, struktur og aktør, prediksjon

\section{Byplanlegging som fag og forskningsfelt}

Denne artikkelen diskuterer noen vitenskapsteoretiske forutsetninger for at byplanlegging skal kunne være mulig og meningsfull, og for at byplanforskning skal kunne frambringe kunnskap som kan gjøre byplanleggingen i stand til å gjøre en positiv forskjell. Med utgangspunkt i min egen forskning på byplanrelaterte problemstillinger, vil jeg argumentere for kritisk realisme som et fruktbart vitenskapsteoretisk ståsted for byplanforskning. Artikkelen diskuterer hvilke muligheter for forskning og planpraksis kritisk realisme angir i forhold til noen sentrale tema innenfor byplanforskning og byplanlegging, illustrert med eksempler fra min egen forskning om bærekraftig byutvikling og boliglokaliseringens innvirkning på transportomfang og bilbruk. Ved siden av å vurdere implikasjonene av et kritisk-realistisk ståsted i forhold til disse temaene, vil relevansen og brukbarheten av kritisk realisme bli vurdert opp mot viktige konkurrerende vitenskapsteoretiske posisjoner, særlig positivisme og poststrukturalisme/ radikal sosialkonstruktivisme. Temaene jeg har valgt å fokusere på, er:

- Mulighet for tverrfaglig integrasjon

- Mulighet for å undersøke årsakssammenhenger mellom samfunnsforhold, romlige bystrukturer og aktørers handlinger

- Mulighet for generalisering og prediksjon

Litt forenklet kan vi si at byplanleggingens formål i moderne samfunn er å bidra til en utvikling av byenes framtidig arealbruk, bygningsmasse og infrastruktur som er gunstigere for samfunnet enn det som ville vært tilfellet uten slik planlegging. Jeg vil hevde at flere av dagens mest utbredte vitenskapsteoretiske posisjoner (f. eks. positivisme og poststrukturalisme) blokkerer - hvis vi skal ta dem på ordet - for at byplanforskning kan bidra med det kunnskapsgrunnlaget som er nødvendig for at byplanleggingen skal kunne oppfylle en slik rolle. Jeg vil samtidig framheve kritisk realisme som en vitenskapsfilosofisk retning som ikke ser ut til å være beheftet med slike, for byplanleggingen selv- $\varnothing$ deleggende, grunnantakelser.

Byplanforskning springer ut av kunnskapsbehovene innenfor en profesjon - byplanlegging. Utøverne av denne profesjonen har bruk for å trekke inn kunnskap fra mange ulike felt, avhengig av den konkrete planleggingsoppgavens karakter. Teoretisk, vitenskaps- 
basert kunnskap er likevel bare en av de kunnskapskategoriene som inngår i begrepet «profesjonell kunnskap». Mange profesjoners kunnskap omfatter også en viss porsjon ubestemmelige, uuttalte og «tause» kunnskaper (Skogheim, 2008). I tillegg besitter profesjonene visse tekniske og håndverksmessige ferdigheter som brukes til å løse profesjonens spesifikke oppgaver. Disse teknikkene kan i større eller mindre grad bygge på erfaringer som er bearbeidet forskningsmessig og/eller være utviklet med utgangspunkt i mer eller mindre eksplisitte vitenskapelige teorier.

Planlegging er et løsningsorientert fag. I motsetning til f. eks. sosiologer eller geografer, som søker å beskrive, forstå og forklare de temaene faget beskjeftiger seg med, har planlegging som eksplisitt formål å gripe inn i virkeligheten og søke å forandre den. Planleggere utformer forslag til løsninger, de utarbeider ikke bare beskrivelser og analyser. Byplanlegging hører altså med blant de formgivende fagene. Men hva er det byplanleggere gir form til? I artikkelen «Planning as a design discipline» framholder den nederlandske planleggingsforskeren Barrie Needham (2000) at det som designes, er både fysisk/tekniske løsninger, planleggingsprosesser og virkemidler for å gjennomføre planene.

Arealbruks-, bebyggelses- og infrastrukturplaner er konkretiserte svar i en gitt kontekst på spørsmål som f. eks.: Til hvilke arealbruksformål (funksjoner/aktiviteter) må det skaffes arealer? Hvor store og hva slags arealer trengs til de ulike arealbruksformålene? Hvordan bør ulike funksjoner/aktiviteter lokaliseres i forhold til hverandre? Hvordan bør de ulike funksjonene/aktivitetene forbindes med hverandre? Hvordan bør en utforme de fysiske omgivelsene som funksjonene/aktivitetene etableres $\mathrm{i}$, for å ivareta både funksjonelle, estetiske, økonomiske, økologiske og trivselsmessige hensyn? Hvilke arealer bør beskyttes mot menneskelige inngrep (Strand, 1991)?

Eksempler på viktige spørsmål omkring planleggingsprosessene er bl.a. disse: Hvordan bør planleggingsprosessen organiseres? Hva er planleggernes rolle i forhold til beslutningstakerne? Hva slags kunnskap bør planleggerne benytte seg av? Hvilke interessegrupper $\emptyset$ ver innflytelse på planleggingen, og kan denne innflytelsen gjøres mer demokratisk? Hvilke midler er til rådighet for å gjennomføre planene? Den måten en gitt planprosess foregår på, uttrykker hvordan man i praksis har valgt å ta stilling til bl.a. disse spørsmålene.

Typisk for de praksis- og designorienterte fagene er den sentrale rollen normative teorier spiller for utøvelsen av faget. Slike normative teorier kombinerer noen verdier (eller mål) med noen antakelser om hvordan disse målene kan realiseres. En planlegger må utvikle posisjoner som gjør det mulig å skille mellom godt og dårlig, og ha oppfatninger om hva som bør gjøres. Planleggeren må ha et «program» som beskriver hva som er riktig eller galt, godt eller dårlig (Landau, 1984). Ved siden av normative teorier om hva slags arealbruk og utbyggingsprinsipper som er $\emptyset$ nskelige, har vi normative teorier som foreskriver hvilke prosedyrer planleggingen bør følge, med ulik vekt på betydningen av målformulering, bruk av ekspertkunnskap, befolkningsmedvirkning osv.

Hvis vi for eksempel ønsker å utvikle en normativ teori for bærekraftig byutvikling, må vi identifisere de verdiene og normene begrepet bærekraftig utvikling omfatter. Dessuten må den normative teorien sette praktikeren i stand til å velge mellom forskjellige strategier for å realisere disse verdiene og normene. Teorien må således også inneholde en vurdering av hvilke tiltak og løsninger som er mer eller mindre effektive midler til å opfylle de gitte målsettingene. Dette krever kunnskap om hvorvidt de aktuelle virkemidlene faktisk kan forventes å bidra til at målene nås. For å utvikle slik kunnskap trengs forskning om hvordan verden er. Resultatene av slike unders $ø$ kelser kan sammenkoples og organiseres i teorier som fors $\varnothing$ ker å beskrive og forklare en større eller mindre del av virkeligheten.

Vi kan dele inn forskningsfeltet planforskning i to tematiske hovedområder (Næss \& Saglie, 2000): Studier av hvilke virkninger ulike måter å utforme og lokalisere bebyggelse og disponere arealer på har for forskjellige konsekvenskategorier, og studier av hvordan offentlig 
planlegging sammen med andre faktorer bidrar til å forme de fysiske omgivelsene. I tillegg fokuserer noe av forskningen på planleggeres faglige arbeidsmetoder med sikte på å videreutvikle disse. Den kunnskapsbasen som er særegen for planleggingsfaget, ligger i hovedsak innenfor disse tre temaene. Rundt denne kjernen ligger en «ytre sfære» med støttekunnskap som planleggere henter inn etter behov, avhengig av den konkrete planleggingssituasjonen. Dette kan dreie seg om både naturvitenskapelig kunnskap (biologi, fysikk, geologi, naturgeografi osv.), samfunnsvitenskapelig kunnskap (sosiologi, statsvitenskap, samfunnsgeografi, økonomi osv.) og kunnskap fra humanistiske fag (historie, kulturstudier, estetikk, etikk mv.). Også planleggingsfagets kjerneområder bygger på kunnskap, metoder og teoretiske perspektiver fra flere disipliner. Disse kjerneområdene danner altså ikke noen egen vitenskapelig disiplin, men kan heller ses på som en arena der fagfolk med forskjellig disiplinbakgrunn samles for å arbeide praktisk eller teoretisk med problemstillinger i skjæringsfelt mellom ulike disipliner.

Byplanlegging dreier seg om romlige forhold. I internasjonal europeisk sammenheng er spatial planning den vanligste betegnelsen på slik planlegging. Rom er imidlertid et begrep med mange dimensjoner, og innenfor samfunnsfagene har det ofte stått strid om hvordan dette begrepet best kan forstås. Som jeg har argumentert for i en tidligere artikkel i dette tidsskriftet (Næss, 2008), går problemstillingene og utfordringene som by- og regionplanleggere fors $\varnothing \mathrm{ker}$ å hanskes med på tvers av grensene mellom ulike disipliner, og planleggerne må derfor benytte teorier og begrep fra ulike felt for å forstå de situasjonene de arbeider med. Derfor har de også bruk for å kombinere ulike forståelser av romlige forhold: som absolutt rom, relativt rom, relasjonelt rom, opplevd rom og som sosialt konstruert rom. En slik tverrfaglig orientering er imidlertid vanskelig å forene med visse vitenskapsteoretiske posisjoner - noe jeg vil komme tilbake til senere i artikkelen.

Som forsker innenfor et saksfelt i grenselandet mellom samfunnsvitenskap, naturvitenskap og humaniora har jeg ofte følt ubehag ved de rigide posisjonene som på den ene side positivismen og på den andre siden hermeneutikken innebærer. Verken positivismens kontekstløshet og tro på universelle årsak-virkningsrelasjoner av typen «hver gang $\mathrm{x}$, så $\mathrm{y}$ », eller hermeneutikkens oppfatning om at forskning dreier seg om å fortolke og forstå enkelttilfeller, med avvisning av årsaksforklaringer, generalisering og prediksjon, synes å passe med forskningsbehovene innenfor byplanlegging. Ikke minst er disse posisjonene problematiske i forhold til et av hovedtemaene for min egen forskning, nemlig bystrukturenes innvirkning på transporten. Undersøkelsene våre innenfor dette temaet forutsetter at strukturer har en virkelig eksistens, at årsakene som påvirker folks transportadferd er mange og kontekstavhengige, at strukturer kan ha kausal påvirkningsevne, og at det er legitimt å kombinere kvalitative og kvantitative forskningsmetoder. Det er vanskelig å forestille seg forskning baseret på disse forutsetningene innenfor f. eks. et positivistisk, rent hermeneutisk eller radikalt sosialkonstruktivistisk paradigme. Innenfor disse paradigmene ville det sannsynligvis bli betraktet som illegitimt, eller i beste fall irrelevant, å unders $\varnothing$ ke og forklare f. eks. hvordan boligens lokalisering innenfor byregionen påvirker de individuelle beboernes transporthandlinger så vel som transportmønstrene på aggregert nivå. Kritisk realisme representerer her et attraktivt alternativ, siden den ikke a priori utelukker visse forskningstema eller forskningsdesign.

\section{Kritisk realisme}

Kritisk realisme, slik den blir presentert av bl.a. Bhaskar (1993, 1998 og 2008), Sayer (1992), Archer (2000), Danermark et al. (2001) og Buch-Hansen \& Nielsen (2005), tilbyr en vitenskapsteoretisk plattform som synes mer relevant for byplanrelatert forskning enn mange andre plattformer. Kritisk realisme ble opprinnelig formulert av Roy Bhaskar med bøkene «A realist theory of science» (først publisert i 1975) og «The possibility of naturalism» (først 
publisert i 1979), i kontrast til en annen form for ontologisk realisme, nemlig positivismens empiriske realisme, som hevder at virkeligheten bare består av det som kan efares med menneskenes sanser. Bhaskars tilbakevisning av positivismens empiristiske ontologi og kausalitetsforståelse stod sentralt i utviklingen av kritisk realisme som et radikalt og helhetsorienteret alternativ til positivismen. Samtidig distanserer kritisk realisme seg fra postmodernismens «tomme» realisme, der sannhet blir fullstendig relativert i forhold til diskurser på overflaten av virkeligheten, slik at man på forhånd må gi opp å si noe om det som eksisterer utenfor disse diskursene (Bhaskar, 1998 og 2008; Buch-Hansen \& Nielsen, 2005).

Ifølge kritisk realisme eksisterer verden uavhengig av hvilken kunnskap vi har om den, og denne kunnskapen er både feilbarlig og teoribeheftet. Det som skjer i verden - i naturen så vel som i samfunnet - er et resultat av årsakskrefter som virker gjennom en rekke generative mekanismer. Kritisk realisme skjelner mellom den intransitive og den transitive dimensjonen av virkeligheten. Den intransitive dimensjonen er det som er gjenstand for vitenskapelig kunnskap: årsakskreftene og de generative mekanismene som eksisterer enten vi har kunnskap om dem eller ikke. Den transitive dimensjonen er forestillingene våre om det som eksisterer. Teorier er en del av den transitive dimensjonen. De er feilbarlige - de kan alltid bli overgått av nye teorier.

Ved siden av inndelingen i den transitive og intransitive dimensjonen, opererer kritisk realisme med en inndeling av virkeligheten i tre domener: Det empiriske, det faktiske og det reelle. Det empiriske domenet omfatter de situasjonene og hendelsene som blir gjort til gjenstand for vitenskapelig observasjon. Det faktiske domenet omfatter alle de situasjonene og hendelsene som utspiller seg, enten de blir registrert som data i vitenskapelige unders $\emptyset$ kelser eller ikke. Det empiriske domenet er altså en (meget liten) delmengde av det faktiske domenet. Det reelle domenet omfatter, foruten de fenomenene som inngår i det empiriske og det faktiske domenet, også de underliggende strukturene, mekanismene, kausale potensialene og tilbøyelighetene som forårsaker og utgjør forutsetninger for manifeste hendelser og situasjoner. Et nærliggende eksempel fra naturvitenskapen på en slik kausal kraft er gravitasjonen.

Kritisk realisme betrakter kausalitet som generative mekanismer. Målet med vitenskapelig forskning er å forklare observerbare fenomener ved å avdekke slike underliggende årsaksmekanismer. Objekter har egenskaper som gjør dem i stand til å utøve visse former for påvirkninger på andre objekter og/eller gjør dem mottakelige for visse påvirkninger fra andre objekter. Ifølge kritisk realisme består virkeligheten for det meste av åpne systemer der empiriske regelmessigheter sjelden forekommer spontant. I åpne systemer er mange ulike årsaksfaktorer til stede samtidig. Noen av disse forsterker hverandre, andre motvirker hverandre, og noen aktiveres bare under påvirkning fra andre årsaksfaktorer. Alt dette varierer med den spesifikke konteksten. Kritisk realismes årsaksbegrep er dermed vesensforskjellig fra det empiristiske årsaksbegrepet slik det ble formulert av syttenhundretallsfilosofen David Hume, som oppfattet kausalitet som konstante kombinasjoner av omstendigheter og begivenheter («hver gang $\mathrm{X}$, så $\mathrm{Y} »)$.

Som det framgår ovenfor, er årsaksforklaringer et viktig begrep i kritisk realisme. Gjennom en stor del av det tyvende århundret har en dikotomi mellom verstehen (fortolkende forståelse) og erklären (årsaksforklaring) blitt stilt opp som en sentral motsetning i debatter om samfunnsvitenskapenes erkjennelsesteoretiske grunnlag, formål og metoder (Bransen, 2001). I tråd med dette er årsaksforklaringer ofte blitt satt i kontrast til formålsforklaringer, forstått som forklaringer av formålsrettet handling. ̊̊ anerkjenne viktigheten av fortolkende forståelse utelukker imidletid ikke at årsaksforklaringer kan inngå som elementer i formålsforklaringer. Ifølge kritisk realisme er det dessuten rimelig å betrakte også folks formål eller 
beveggrunner som årsaker (Bhaskar, 1998; Sayer, 2000). Årsaksmekanismer kan omfatte individers holdninger og kunnskapsressurser så vel som intersubjektive meningsdannelser.

For å måle den nøyaktige effekten av en bestemt årsaksfaktor, må man ifølge kritisk realisme konstruere et lukket system. Det er nettopp dette man gjør i naturvitenskapelige eksperimenter. I samfunnsvitenskapene er det av ulike grunner mye vanskeligere å skape lukkete systemer. Det betyr likevel ikke at det er umulig å identifisere samfunnsmessige årsaksmekanismer. Ifølge kritisk realisme er enhver menneskelig organisasjon - fra familiehusholdningen til offentlig forvaltning, kjøpesenteret eller fabrikken - eksempler på delvis lukkete systemer. Denne begrensete lukketheten innenfor deler av samfunnet oppnås ved at mennesker er internt forbundet med hverandre. Noen av disse relasjonene og reguleringene er mer sentrale enn andre og kan resultere i regelmessigheter som avspeiler seg på mange områder av det sosiale livet (Danermark et al., 2001; Karlsson, 2009).

Virkeligheten består ifølge kritisk realisme av ulike lag (strata), der nye egenskaper og årsakskrefter oppstår (ved emergens) på hvert lag, sammenliknet med laget nedenfor. Årsakskreftene fra de lavere lagene eksisterer imidlertid også i de høyere. De ulike lagene utgjør ofte forskningsområder for hver sine ulike disipliner. I rekkefølge fra de mest grunnleggende (laveste) til de mer komplekse (høyere) lagene, kan man f. eks. snakke om de fenomenene som behandles innenfor fysikk, kjemi, biologi, psykologi og sosiologi som ulike lag av virkeligheten. Hvordan man konkret velger å dele inn lagene, vil avhenge av forskningstemaet, og selve inndelingen må sies å være en sosial konstruksjon og hører dermed til den transitive dimensjonen av virkeligheten. Men selve fenomenet emergens - at det på høyere strata oppstår nye årsakskrefter som er avhengige av de lavere lagene og som samtidig kan virke tilbake på disse - er reelt og tilhører den intransitive dimensjonen (Bhaskar, 2008).

I hvor stor grad de «høyere» lagene virker tilbake på de «lavere», varierer både med hvilke lag det er snakk om, og også mellom ulike epoker. Menneskesamfunnet er f. eks. emergent fra psykologiske, biologiske, naturgeografiske og grunnleggende fysiske vilkår, men virker i dag tilbake på naturgrunnlaget med atskillig større (og mer ødeleggende) kraft enn i steinalderen. Av spesiell interesse for byplanforskning så vel som for samfunnsforskning generelt er forholdet mellom sosiale strukturer (herunder også menneskeskapte materielle strukturer) og aktører. Kritisk realisme anser at både strukturer og aktører har særskilte egenskaper og kausale krefter. Bortsett fra de naturgitte forutsetningene, er de strukturene som omgir oss, på forskjellige måter «sosialt konstruerte». Det konstruerte kan være fysiske objekter, f. eks. bygninger eller veier, eller mer immaterielle strukturer som f. eks. eiendomsforholdene og de økonomiske betingelsene, eller rådende oppfatninger og kulturelle tradisjoner. Når de ulike strukturene først er blitt skapt, har de kausale krefter og egenskaper som er forskjellige fra og virker ut over summen av de aktørkreftene som forårsaket strukturenes tilblivelse. Selv om strukturer blir skapt av aktørers handlinger, inngår de altså som betingelser for framtidige handlinger, ofte lenge etter at de menneskene som i sin tid skapte strukturene, er døde. Samtidig blir strukturene modifisert og forandret av menneskers handlinger, oftest gradvis og langsomt, men noen ganger mer dramatisk og raskt (Bhaskar, 1993).

Kritiske realister legger vekt på at også kunnskap er et sosialt produkt. Denne sosialt konstruerte kunnskapen er feilbarlig, men ikke alle utsagn er like feilbarlige. Noen utsagn er teoretisk og empirisk velbegrunnete, andre er det ikke. Til tross for at all kunnskap er feilbarlig, mener kritiske realister det er mulig å skjelne mellom utsagn med høy og lav troverdighet. Kritisk realisme står med andre ord for en kombinasjon av ontologisk realisme, epistemologisk relativisme og vurderingsmessig rasjonalisme.

Kritiske realister understreker videre at kunnskap er om noe (nemlig om virkelighetens intransitive dimensjon). Naturen eksisterer uavhengig av hva vi vet om den (selv om den påvirkes og endres gjennom menneskers handlinger). Heller ikke den sosiale virkeligheten 
blir konstruert av forskerne. Den er skapt av aktører gjennom historien og blir reprodusert og endret, ofte ubevisst, gjennom sosiale handlinger og gjensidige påvirkninger blant alle samfunnsaktørene. Samfunnsforskning kan påvirke samfunnsutviklingen, men dette skjer i så fall i et mye lengre tidsperspektiv enn perioden da forskningen det er snakk om, ble utført.

\section{Tverrfaglig integrasjon}

Som nevnt er byplanlegging et problemorientert praksis- og forskningsfelt som er avhengig av å ta i bruk og syntetisere forståelsesrammer, begrepsapparat og kunnskap fra mange ulike disipliner. Dette krever en ikke-reduksjonistisk tilnærming, der ulike disipliners perspektiver ikke betraktes som gjensidig utelukkende, men anerkjennes som representasjoner av forskjellige deler av virkeligheten. Byer er komplekse sosiomaterielle systemer der en rekke ulike kontekster, strukturer, endringer og situasjoner påvirker hverandre. Det er gjensidige avhengigheter mellom en bys naturgrunnlag og økologiske situasjon, de bygde omgivelsene, de $\varnothing$ konomiske forholdene og innbyggernes sosiale liv og levekår. Resultatet av ett enkelt virkemiddel i byutviklingen avhenger vanligvis av hvilke påvirkninger som samtidig skjer fra en rekke andre faktorer. Strategier for å fremme $\varnothing$ konomiske, sosiale og miljømessige hensyn i byutviklingen har vanligvis viktige sidevirkninger som kan skape positive synergier så vel som konflikter.

Denne kompleksiteten reiser en rekke utfordringer for teoretisering og forskning om byutvikling og byplanlegging. For å forstå hvilken virkning en konkret endring eller et konkret virkemiddel har hatt, er det f. eks. ikke tilstrekkelig å se på situasjonen før og etter iverksettingen. Det er nødvendig å korrigere for virkningen av alle andre faktorer som også kan ha påvirket utfallet. Hvis ikke, risikerer vi å trekke feilaktige slutninger om hvilken effekt det undersøkte virkemidlet faktisk har hatt. En slik kontrafaktisk vurdering krever kunnskap om hvordan hver av disse andre faktorene tenderer til å påvirke situasjonen. Siden de faktorene som kan tenkes å spille inn, kan omfatte både fysiske, sosiale, psykologiske, kulturelle, økonomiske og andre forhold, er det sjelden at kunnskap om de ulike påvirkningsfaktorenes virkemåte finnes innenfor en enkelt disiplin. Empiriske undersøkelser av årsakvirkningssammenhenger i komplekse systemer som f. eks. byer krever derfor tverrfaglig integrasjon av kunnskap fra ulike disipliner. Teorier og forskningsresultater fra ulike fag må tas i bruk både for å kunne tolke informasjon fra kvalitative undersøkelser riktig, så vel som for å kunne vite hvilke variabler det er nødvendig å kontrollere for i statistiske eller kvasieksperimentelle forskningsdesign.

Tverrvitenskapelig forskning forutsetter at man opererer innenfor et vitenskapsteoretisk paradigme som ikke på forhånd utelukker deler av virkeligheten fra å komme i betraktning. Kritisk realisme er en vitenskapsteoretisk plattform som i særlig grad fremmer tverrfaglighet. Ifølge Bhaskar og Danermark (2006) er kritisk realisme maksimalt inkluderende når det gjelder å tillate empirisk unders $\emptyset$ kelse av årsakskrefter fra ulike lag (strata) av virkeligheten, samtidig som den også er maksimalt inkluderende mht. å ta opp i seg på en udogmatisk måte innsikt fra andre metateoretiske retninger uten å inkorporere problematiske og uholdbare antakelser forfektet av disse retningene. Kritisk realisme ser f. eks. på hermeneutikk som et grunnvilkår for menneskelig erkjennelse og på hermeneutisk forskning som den foretrukne tilnærmingen for å oppnå innsikt om de motivasjonene, begrunnelsene og subjektive fortolkningsmønstrene som ligger bak menneskers handlinger. Hermeneutikk er også den opplagte metoden for å belyse f. eks. det estetiske innholdet i de bygde omgivelsene. Kritisk realisme avviser imidlertid hermeneutikkens oppfatning om at den sosiale virkeligheten grunnleggende ikke består av annet enn de begrepene aktørene har dannet seg om den (Bhaskar \& Danermark, 2006). Kritiske realister vil også avvise at kvalitativ fortolkning av «tekst» og «tegn» er den eneste akseptable forskningsmetoden. 
Ifølge kritisk realisme må konkrete ting eller begivenheter i åpne systemer normalt forklares med flere ulike årsaksmekanismer. Disse vil i mange tilfelle være radikalt forskjellige (og dermed sortere under ulike disipliner), med «forankring» i ulike lag eller aspekter av virkeligheten (Bhaskar og Danermark, ibid.). I studier av hvordan byenes romlige struktur påvirker innbyggernes transportatferd er det f. eks. nødvendig å trekke veksler på transportgeografiske teorier (bl.a. lokaliseringsteori og tidsgeografi), transportøkonomisk teori, bymorfologiske teorier og begreper så vel som mobilitetssosiologi. I et bredere perspektiv hører de fenomenene som inngår i forklaringer av hvor bærekraftig eller ikkebærekraftig byer utvikler seg, delvis inn under naturvitenskapene, delvis under samfunnsvitenskapene, og de er delvis av normativ eller etisk karakter. De opererer også på ulike geografiske eller organisatoriske nivå. Situasjoner, begivenheter og prosesser som påvirker i hvor stor grad byutviklingen oppfyller bærekraft-kriterier må derfor forstås som utslag av både fysiske, biologiske, sosioøkonomiske, kulturelle og normative mekanismer, kontekster og karakteristiske effekter (Høyer og Næss, 2008).

Bhaskar og Danermark (2006) framholder at samfunnslivet må betraktes ut fra en forståelse av menneskets natur som et fire-plans samfunnsvesen (four-planar social being). Dette innebærer at enhver sosial begivenhet må forstås ut fra fire dialektisk gjensidig avhengige plan: [a] materielle transaksjoner med naturen, [b] sosial interaksjon mellom aktører, [c] samfunnsstrukturelle forhold, og [d] lagdelingen av aktørers (fysiske og mentale) personlige egenskaper. Alle disse aspektene bør belyses i forskning om byutviklingens årsaker eller konsekvenser. For å gjøre dette litt mer konkret, vil jeg vise noen eksempler på konsekvenser som har med byutviklingen å gjøre på hvert av de fire planene. På hvert plan er det også årsaksfaktorer som påvirker forhold innenfor de andre planene så vel som innenfor det planet der de selv finnes. Av plasshensyn vil jeg imidlertid begrense eksemplene til konsekvenser på de fire planene.

Konsekvenser på det første planet (a) omfatter f. eks. byutviklingens virkninger på naturmiljøet. Konsekvenser av byutviklingen i form av at folk velger å utføre aktiviteter (f. eks. innkjøp) andre steder enn tidligere og endrer transportatferd, er eksempler på virkninger av byutviklingen innenfor kategori b. Aktuelle konsekvenser innenfor det samfunnsstrukturelle planet (kategori c) kan f. eks. omfatte virkninger av forhold på boligmarkedet på boligbyggingsprosjekter, eller konsekvenser av slike prosjekter for den samlete bystrukturen. Også endringer i byenes romlige og sosiale strukturer som følge av ulike aktørers (bl.a. byplanleggeres) handlinger hører med på dette planet. Konsekvenser for lagdelingen av aktørers personlige egenskaper (kategori d) kan f. eks. omfatte somatiske og mentale helsemessige virkninger av byutviklingen som følge av støy og forurensning, samt motivasjon for politisk handling eller flytting til et mindre eksponert nabolag som følge av disse erfaringene. Hvordan plan- og beslutningsprosessene om byutvikling virker inn på folks selvaktelse, verdier, muligheter for personlig utvikling og motivasjon for å delta i demokratiske prosesser, hører også med til denne kategorien. Det samme gjør ulike diskursers (hegemoniske og alternative) innvirkning på aktørers oppfatninger om hvilke endringer (hvis i det hele tatt noen) som er nødvendige for å oppnå en bærekraftig byutvikling, og vilkårene for å gjennomføre slike endringer.

De fysiske, biologiske, sosioøkonomiske, kulturelle og normative mekanismene som er involvert i byutviklingen, opererer dessuten i ulik skala, innenfor makroskopiske (eller overordnete) så vel som mer og detaljerte og underliggende strukturer og mekanismer. Bevissthet om slike skalaforskjeller er avgjørende i forskning om byplanlegging og byutvikling, særlig for studier med et bærekraftperspektiv. For eksempel bunner trolig mye av uenigheten mellom tilhengere av «grønne» og «kompakte» idealmodeller for miljømessig bærekraftige byer $\mathrm{i}$ at de fokuserer på problemer og utfordringer på ulikt geografisk nivå: Mens den «kompakte» bymodellen særlig har lagt vekt på konsekvensene av byutviklingen 
for de større naturmiljøene og økosystemene som omgir byen (fra de nærmeste natur- og kulturlandskapene til det globale nivået), har tilhengerne av den «grønne» bymodellen vært mest opptatt av miljøet innenfor byen selv. En miljømessig virkelig bærekraftig byutvikling ville imidlertid kreve en integrering av elementer både fra det førstnevnte («byen i $\varnothing$ kologien») og det sistnevnte perspektivet («økologien i byen»). På tilsvarende måte bør analyser av sosiale aspekter av bærekraftig utvikling omfatte både lokale og globale virkninger og kombinere forståelse av praksiser innenfor bestemte befolkningsgrupper med en analyse av hvordan ulike virkemidler og utviklingstrekk virker inn på fordelingen av fordeler og ulemper mellom ulike befolkningsgrupper.

Kritisk realisme anser at et mangfold av forskningsmetoder kan anbefales så lenge de tar hensyn til forskningsobjektets ontologiske status (Danermark et al., 2001). Både kvalitative og kvantitative metoder har sin plass - men i motsetning til positivismen er man i kritisk realisme langt mer tilbakeholden med å ta statistiske sammenhenger som uttrykk for årsakssammenhenger. Teknikker som f. eks. regresjonsanalyser er verktøy som gjør det mulig å belyse mønstre $\mathrm{i}$ et empirisk materiale på en mer nyansert og sofistikert måte, men slike analyser kan ikke påvise kausalitet. Kombinert med teoretiske resonnementer og kvalitative empiriske studier kan de imidlertid utgjøre en del av den empiriske dokumentasjonen for årsakssammenhenger (Næss, 2004).

Kritisk realismes inkluderende karakter når det gjelder metodemangfold, forståelse for de multikausale situasjonene man står overfor i åpne systemer og anerkjennelse av årsaksmekanismer innenfor ulike «lag» av virkeligheten, gjør denne vitenskapsteoretiske posisjonen særlig godt egnet som plattform for tverrrfaglig forskning. Dette gjelder ikke minst forskning på temaer som har med bærekraftig byutvikling å gjøre.

Mens kritisk realisme ser tverrfaglig integrasjon som helt nødvendig for å kunne forstå fenomener som inngår i komplekse systemer, er det mange av dagens mest innflytelsesrike vitenskapsfilosofiske perspektiver som neglisjerer og ekskluderer viktige deler av virkeligheten. Det gjelder f. eks. positivisme, empirisisme, nykantianisme og radikal sosialkonstruktivisme, som har blitt kritisert (Bhaskar \& Danermark, 2006) for å insistere på standpunkter som i praksis ville gjøre det umulig å frambringe viten om mangefasetterte og komplekse fenomener (som f. eks. byutvikling og konsekvenser av denne). Innenfor et positivistisk paradigme vil f. eks. kunnskap basert på observasjoner som ikke lar seg kvantifisere og behandle matematisk, bli sett på som mindre solid og kanskje bli avvist som rent subjektive meninger. På den andre siden innebærer en radikal sosialkonstruktivistisk posisjon en utvisking av forskjellen mellom sosiale objekters eksistens og de deltakende aktørenes oppfatning og forståelse av disse objektene. For forskning om byutvikling og byplanlegging vil radikal sosialkonstruktivisme typisk dirigere all oppmerksomheten mot de kulturelle prosessene som fører til at visse sider ved byutviklingen blir oppfattet som problematiske (f. eks. i forhold til miljø- eller sosiale hensyn), mens det i praksis anses som umulig å si noe med vitenskapelig gyldighet om verken de underliggende, strukturelle mekanismene som forårsaker de problematiske utviklingstrekkene eller konsekvensene disse sidene av byutviklingen har for naturmiljø eller sosiale forhold.

\section{Årsakssammenhenger mellom samfunnsforhold, romlige bystrukturer og aktørers handlinger}

Som nevnt foran, er ett av hovedtemaene i byplanforskningen å undersøke hvilke virkninger ulike måter å utforme og lokalisere bebyggelse og disponere arealer på, har for mennesker og miljø. Et annet hovedtema er hvordan offentlig planlegging sammen med andre faktorer bidrar til å forme de fysiske omgivelsene. Begge disse hovedtemaene berører forholdet mellom aktører og strukturer. For at byplanleggingen i det hele tatt skal kunne ha noen mening, må byenes romlig/materielle strukturer ha innflytelse på menneskers trivsel, 
handlinger og velferd og på miljøet. Hvis ikke, ville det ikke spille noen rolle hvordan disse strukturene utviklet seg, og det ville dermed heller ikke være noen grunn for samfunnet til å engasjere seg $\mathrm{i}$ form av offentlig byplanlegging. Heller ikke ville det være noen grunn for private aktører som f. eks. byggherrer og eiendomsutviklere til å bygge eller endre arealbruken. For at byplanlegging skal være mulig, må byens romlig/materielle strukturer samtidig være foranderlige. De må kunne endres gjennom aktørers (bl.a. byplanleggeres) handlinger. Samtidig opptrer byplanleggere og andre endringsagenter ikke i et vakuum, men er under innflytelse fra en rekke samfunnsstrukturelle forhold (f. eks. eiendomsforhold, lovverk, samfunnets grunnleggende økonomiske system osv.).

Denne forståelsen av forholdet mellom strukturer og aktører, som jeg vil hevde ligger som en implisitt forutsetning for all byplanlegging og byplanforskning, er i tråd med kritisk realismes oppfatning om at både strukturer og aktører har særskilte egenskaper og kausale krefter (Bhaskar, 1993; Archer, 2000; Sayer, 2000; Danermark et al., 2001). Menneskeskapte fysiske strukturer, samfunnets politiske konstitusjon, det rådende $\varnothing$ konomiske systemet og andre relativt stabile egenskaper ved samfunnet vårt er «sosialt konstruerte» og blir ofte forstått som resultater av diskurser. Dette forhindrer imidlertid ikke at de i en gitt situasjon og for visse analyseformål kan betraktes som «ekstradiskursive» strukturer. Det kan f. eks. være rimelig hvis de diskursene som i sin tid produserte strukturene, ligger langt tilbake i tid i forhold til de sosiale handlingene vi ønsker å forklare. De individene som strukturene påvirker, er dessuten ikke nødvendigvis de samme som de som konstruerte disse strukturene. Når de ulike strukturene først er blitt til, har de kausale krefter og egenskaper som er forskjellige fra og virker ut over summen av de aktørkreftene som skapte dem. Bystrukturene utgjør f. eks. både begrensninger og muligheter for våre konkrete handlinger i dagliglivet.

Menneskeskapte materielle strukturer (f. eks. veier og bygninger) kan ha stor bestandighet. Gatenettet i de indre delene av de største norske byene er fortsatt preget av det gatemønsteret som ble etablert for flere hundre år siden. Samtidig blir også de materielle strukturene modifisert og forandret av menneskers handlinger, oftest gradvis og langsomt, men noen ganger mer dramatisk og raskt. Formålet med byplanleggingen (så vel som den kunnskapsproduksjonen denne planleggingen bygger på) er som nevnt å påvirke disse endringsprosessene $\mathrm{i}$ en for samfunnet gunstigere retning.

En kritisk-realistisk forståelse av årsakssammenhenger mellom strukturer og aktører blir forhåpentlig lettere å forstå gjennom det følgende eksemplet, hentet fra forskning om bystrukturers påvirkning på innbyggernes transportaktivitet.

Årsaksfaktorene som påvirker folks transportaktivitet omfatter politiske og økonomiske samfunnsstrukturer, materielle og romlige strukturer så vel som individenes $\emptyset$ konomiske, kognitive og fysiske ressurser, behov, ønsker og forpliktelser. Folk som bor i samme nabolag, kan derfor ha vidt forskjellige transportmønstre. Likevel vil det være en tendens til at forstadsbeboere reiser lengre til hverdags og utfører en større del av transporten med bil enn de som bor tettere på sentrum. Dette har sammenheng med at de som bor nær sentrum, som regel kan nå et stort antall arbeidsplasser og servicetilbud i kort avstand fra boligen. Korte avstander gjør dessuten at en større del av reisemålene kan nås med sykkel eller til fots. I forstedene er mulighetene for å finne en passende arbeidsplass i nærheten av boligen dårligere, de lokale servicetilbudene mer begrensete, og befolkningstettheten er ofte for lav til å gi grunnlag for et godt kollektivt transporttilbud. Folk med samme ønsker, ressurser og behov kan derfor ha vidt forskjellige transportmønstre, avhengig bl.a. av hvor de bor.

En beboer i en av de perifere forstedene i Københavnregionen kan f. eks. velge å reise 33 kilometer med bil om morgenen fordi denne handlingen ifølge vedkommendes oppfatning er det beste middelet til å realisere et ønske om å nå fram til arbeidsplassen i tide. En annen person, bosatt i bykjernen, kan i stedet velge å sykle $2 \mathrm{~km}$ om morgenen for å realisere et helt 
tilsvarende $\emptyset$ nske. Et felles $\emptyset$ nske - å nå fram til arbeidsstedet innen arbeidsdagen begynner blir altså realisert med helt ulike midler fordi avstanden mellom bolig og arbeidssted er forskjellig.

Med den gitte romlige fordelingen av arbeidsplasser av ulike slag, foreligger det et «strukturelt imperativ»som innebærer at beboere i de ytre forstedene tvinges til å akseptere lengre arbeidsreiser for å finne en passende jobb, med mindre det skulle finnes en virksomhet i lokalområdet med arbeidsplasser som matcher vedkommende beboers kvalifikasjoner og hun/han får ansettelse i denne lokale virksomheten. Den sistnevnte muligheten (som riktignok har lav sannsynlighet) innebærer at en perifer boliglokalisering ikke alltid skaper lange arbeidsreiser, men den tenderer til å gjøre det. Den faktiske konfigurasjonen avhenger av hvordan folk i praksis søker ledige jobber og oppnår ansettelse innenfor byregionens arbeidsmarked. Innbyggerne i de ytre delene tenderer derfor til å reise lengre til og fra jobben (med mindre de gir avkall på friheten til å velge mellom like mange jobbmuligheter som innbyggerne i de sentrale bydelene). Gitt den sterkere sentraliseringen av arbeidsplasser enn boliger innenfor Københavnregionen, ville selv ikke en slik villighet til å redusere valgmulighetene hindre at en betydelig del av beboerne i de ytre forstedene fortsatt ville stå overfor valget mellom lange arbeidsreiser eller arbeidsløshet.

Årsakssammenhengen på aggregert nivå mellom byspredning med flere boliger i forstedene og $\varnothing \mathrm{kt}$ biltrafikk avhenger av at det er en viss regelmessighet (i form av tendenser, ikke som deterministiske samsvar) i innbyggernes prioritering mellom ulike rasjonaler (bakgrunner, motiver og begrunnelser) for deltakelse i aktiviteter utenfor hjemmet, lokalisering av disse aktivitetene, reisemåte og reiserute. Med et gitt sett av dominerende transportrasjonaler blant innbyggerne, oppstår det (ved emergens) årsakssammenhenger på by-nivå mellom bystruktur og typiske transportmønstre, med basis i årsakssammenhengene mellom boliglokalisering og reiseaktivitet på individuelt nivå (Næss, 2013; Næss \& Strand, 2012).

Som byplanforsker finner jeg kritisk realismes måte å betrakte forholdet mellom strukturer og aktører på, meget relevant og anvendelig. Det er imidlertid en tradisjon innenfor innflytelsesrike deler av samfunnsvitenskapen for å avvise at de fysisk/romlige omgivelsene har noen nevneverdig påvirkning på menneskers handlinger (se Benton, 2001 for en kritikk av dette). Den kjente samfunnsgeografen Manuel Castells (1977) har f. eks. hevdet at alt det rommet eventuelt måtte bety, ligger i de sosiale, økonomiske og politiske kreftene som har produsert det. Innenfor sosiologien er det en lang tradisjon for å anse at sosiale fenomener bare kan forklares ved å forbinde dem med andre sosiale fenomener (i motsetning til forklaringer som viser til f.eks. psykologiske, biologiske eller fysiske forhold) (Tonboe, 1993, s. 4; Lidskog, 1998, s. 22). Denne oppfatningen har røtter tilbake til arven fra klassikere som Emile Durkheim og Max Weber (Dunlap \& Catton, 1983). I dag kan denne «rom-blindheten» og avvisningen av romlig-strukturelle forholds betydning for aktørers handlinger og sosiale fenomener gjenfinnes i mye av den poststrukturalistiske litteraturen.

Ifølge den kritisk-realistiske sosiologen Margaret Archer (2000:6) er det særlig blant $\varnothing$ konomer en utbredt tradisjon for å hevde at samfunnsstrukturer ikke er noe annet enn uttrykk for individuelle, instrumentelt rasjonelle aktørers preferanser. En motsatt posisjon betrakter alle menneskelige egenskaper (bortsett fra vår biologiske konstitusjon) som samfunnsskapte. Innenfor denne retningen, representert ved visse diskursteoretikere og deler av den kapitallogiske tradisjonen, reduseres individene til å være «bærere» av strukturer eller diskurser. En tredje posisjon, bl.a. representert ved Giddens' (1984) strukturasjonsteori, anser at strukturer og aktører er gjensidig konstituerende og ikke kan holdes fra hverandre. Det blir dermed ifølge Archer heller ikke mulig å analysere hvordan strukturer og aktører påvirker hverandre, siden verken strukturenes eller aktørenes særskilte egenskaper og påvirkningskrefter kan identifiseres. Denne teorien ser i stor grad bort fra den viktige faseforskjellen 
mellom omgivelsenes påvirkning på våre handlinger og våre handlingers påvirkning av omgivelsene. Giddens' strukturasjonsteori underkommuniserer at vi fødes inn i en samfunnsstrukturell kontekst som allerede eksisterer, og at vi, selv om vi har mulighet til å endre slike strukturer, likevel i enhver konkret handlingssituasjon er undergitt de mulighetene og begrensningene som den konkrete strukturelle konteksten (f. eks. bystrukturen) utgjør. Strukturasjonsteoriens oppfatning av strukturer som normer, fortolkningsskjemaer og maktressurser begrenser også mulighetene for å undersøke makrostrukturelle forhold som $\mathrm{f}$. eks. iboende mekanismer i det økonomiske systemet. Romlig/materielle strukturer ser også ut til å falle utenfor interessefeltet. En tilsvarende nedtoning av betydningen av hierarkiske sosiale strukturer og slike strukturers relative permanens ser ut til å gjelde Foucaults maktteori, der makt ses på som noe flyktig som utøves i strategisk-relasjonelle prosesser, ikke noe man besitter f. eks. i kraft av eiendomsrett og apparat til å beskytte denne (Thomsen, 2000).

Alle de ovenfor nevnte teoriene om strukturer og aktører innebærer, hvis de blir tatt på alvor, betydelige begrensninger i mulighetene for forskning på byplanleggingens vilkår og resultater så vel som på virkningene av ulike former for romlig/materiell byutvikling. Kritisk realisme framstår i så måte som langt mer inkluderende og utgjør en velegnet plattform for forskning på strukturers innvirkning på aktørers handlinger så vel som aktørenes bidrag til å opprettholde eller endre strukturer.

\section{Generalisering og prediksjon}

Hvis byplanleggingen skal kunne bidra til en utvikling av byenes framtidige arealbruk, bygningsmasse og infrastruktur som er gunstig for samfunnet, må det være mulig å forutsi om det er sannsynlig at et bestemt virkemiddel, for eksempel lokaliseringen og utformingen av et nytt bolig- eller arbeidsplassområde, vil føre til en annen (og bedre) måloppnåelse enn andre løsninger. Det er en nødvendig forutsetning for planlegging at man i noen grad er i stand til å forutsi konsekvenser av løsninger. Planleggerne må være i stand til å skjelne mellom effektive, mindre effektive og kontraproduktive midler til å opfylle de målene man ønsker å nå. Det gjelder også utformingen av plan- og beslutningsprosessene (f. eks. hvilken grad av og hva slags befolkningsmedvirkning som er mest i tråd med demokratiske prinsipper) og spørsmålet om offentlig planlegging overhodet vil gjøre noen forskjell, sammenliknet med en rent utbyggerstyrt utvikling. Hvis planleggerne ikke er i stand til å gi velbegrunnete svar på om en foreslått strategi eller plan kan forventes å realisere de formålene den er begrunnet med, vil grunnlaget for kollektive, samfunnsmessige beslutninger være skrøpelig. Da kan beslutningene like gjerne baseres på terningkast som på planlegging.

Mye av tidens vitenskapsteoretiske litteratur preges imidlertid av uttalt skepsis med hensyn til mulighetene for prediksjon (forutsigelse) innenfor samfunnsvitenskapene. Noen forfattere har helt avvist muligheten for å lage prediksjoner om aktiviteter og hendelser $\mathrm{i}$ samfunnet, også når det gjelder gjennomsnittlige eller typiske atferdsmønstre blant et stort antall individer innenfor tidsmessige og romlige avgrensninger (Lincoln og Guba, 1985; Brox, 1989). En slik posisjon, som særlig kommer til uttrykk innenfor poststrukturalisme og andre postmoderne retninger, har dramatiske implikasjoner for offentlig planlegging og politisk styring.

Positivismen opererer i motsetning til dette med symmetri mellom forklaring og prediksjon, der et fenomen anses å kunne forklares ved at det faller inn under en generell lov, som også kan brukes til å forutsi framtidige hendelser eller tilstander. Innenfor positivistisk pregete fag har man hatt sterk tro på at det er mulig å forutsi hvilke framtidige situasjoner tiltak som f. eks. bygging av nye infrastrukturanlegg vil føre til. Bruken av trafikkmodeller for å forutsi hvordan det framtidige trafikkbildet vil bli etter bygging av en ny vei, er et eksempel på dette. Også samfunnsøkonomenes nytte-kostnadsanalyser, der man med noen få talluttrykk 
forsøker å gi svar på hvor samfunnsmessig lønnsomt eller ulønnsomt et prosjekt vil være, er uttrykk for sterk tro på muligheten for å komme med presise forutsigelser om framtiden.

Sammenliknet med de forutsigelsene trafikkingeniører og økonomer utarbeider, er byplanleggernes forutsigelser om konsekvenser av alternative løsninger av en «mykere» art. Som regel blir løsningsalternativer diskutert og sammenliknet kvalitativt. Eventuell kvantifisering begrenser seg vanligvis til enkle beregninger og grove anslag.

\section{Hvor står så kritisk realisme i dette bildet?}

I likhet med positivismen mener kritiske realister at det finnes vitenskapelige lover. Slike lover er mekanismer som eksisterer som en egenskap i virkeligheten. Men i motsetning til positivismen framhever kritisk realisme at de observerbare effektene av vitenskapelige lover varierer mye, avhengig av de konkrete omstendighetene. Særlig gjelder dette innenfor de høyere «lagene»av den stratifiserte virkeligheten. Innenfor kritisk realisme har en rekke teoretikere på bakgrunn av dette avvist mulighetene for prediksjon om forhold i samfunnet (Sayer, 1992; Lawson, 1997; Danermark et al., 2001). Etter hvert har imidlertid et mer nyansert syn fått $\varnothing \mathrm{kt}$ gjennomslag. Der avviser man fortsatt positivismens tro på presise forutsigelser om framtidige situasjoner, men holder samtidig muligheten åpen for kvalitative vurderinger av årsaksfaktorers virkninger, eventuelt supplert med grove anslag over virkningenes størrelsesorden (Næss, 2004; Karlsson, 2009; Næss \& Strand, 2012). Jeg vil bruke et eksempel fra min egen forskning om hvordan ulike former for lokalisering av boligbebyggelse påvirker beboernes transportaktivitet, til å illustrere denne typen «myke» forutsigelser i lys av kritisk realisme.

Undersøkelser i en rekke land har vist at de som bor i forstedene, har mer daglig transport og utfører en større del av transporten med bil enn beboerne i indre og sentrale bydeler. Årsakene til dette ble drøftet tidligere. Slike sammenhenger er også funnet i mine egne undersøkelser i bl.a. Stor-København, Stor-Oslo, Frederikshavn og den kinesiske storbyen Hangzhou. I de fleste av disse undersøkelsene kombinerte vi kvantitative og kvalitative forskningsmetoder. Gjennom kvalitative intervju fikk vi belyst folks transportrasjonaler. Dette hjalp oss med å avdekke viktige ledd i de årsaksmekanismene som bystrukturen påvirker de enkelte individenes transportatferd gjennom. For å kunne identifisere bystrukturens effekter på transportatferden empirisk på et aggregert nivå, ble det dessuten utført en rekke statistiske analyser basert på spørreskjemaundersøkelser av transportaktivitet blant beboere bosatt i forskjellige deler av byregionene ${ }^{1}$. Nedenfor vil jeg bruke undersøkelsen i Stor-København som eksempel (Næss, 2004, 2005 og 2009).

Formålet med Københavnundersøkelsen var å frambringe kunnskap som kan være nyttig i arbeidet for mer bærekraftig byutvikling. Studien er et bidrag til teoriutvikling om hvordan bystrukturer virker inn på transporten. Hensikten er selvfølgelig at slik kunnskap ikke bare skal kunne brukes i Københavnregionen, men også andre steder. Formålet er dessuten ikke bare å forklare og forstå tingenes tilstand, men å gjøre byplanleggere bedre i stand til å vurdere transportkonsekvenser av ulike strategier for framtidig byutvikling. Hvis resultatene fra undersøkelsen skal kunne være brukbare for praktisk planlegging i andre kontekster, må det gjøres generaliseringer i rom såvel som i tid.

La oss først se på generalisering i rom. Som nevnt framholder kritisk realisme at det som kan generaliseres, er hvordan en gitt årsaksmekanisme tenderer til å virke, ikke hvilken situasjon som oppstår som følge av at årsaksfaktoren er til stede. I hvilken grad kan man ut fra et kritisk-realistisk ståsted generalisere boliglokaliseringens innvirkning på transportatferden blant deltakerne i Københavnundersøkelsen? Vi står her overfor generalisering på to nivå: Fra unders $\varnothing$ kelsesdeltakerne til innbyggerne $\mathrm{i}$ hele Københavnregionen, og fra Københavnregionen til andre byområder. 
I Københavnundersøkelsen ble boligområdene ikke trukket tilfeldig, men ble utvalgt i henhold til bystrukturelle og sosiodemografiske kriterier. Konsentrasjonen av respondenter innenfor et begrenset antall lokaliteter tillot en grundigere registrering av kontekstuelle forhold i hvert av de valgte områdene. Men denne måten å velge ut respondenter på, gjør det problematisk å utføre statistiske generaliseringer fra utvalget av respondenter til hele befolkningen i Københavnregionen. De beregnete statistiske signifikansnivåene indikerer derfor bare hvor sikre de forskjellige sammenhengene er internt blant respondentene.

En generalisering fra utvalget vårt til innbyggerne i hele Københavnregionen må i stedet baseres på en rekke kvalitative vurderinger: I hvor stor grad avviker de utvalgte boligområdene, sett under ett, fra Københavnregionens boligområder generelt, med hensyn til egenskaper som er relevante for forskningsspørsmålene våre? I hvilken grad skiller relevante egenskaper ved respondenterne, betraktet som gruppe, seg fra den samlete befolkningen i Københavnregionen? Virker det sannsynlig og rimelig å anta at forskjeller mellom utvalget og befolkningen i Københavnregionen har hatt avgjørende innvirkning på de sammenhengene vi har funnet mellom boliglokalisering og transport? En liknende kvalitativ vurdering må skje hvis vi vil gjøre generaliseringer fra Københavnregionen til andre skandinaviske eller europeiske byregioner og byer. Det samme gjelder selvfølgelig også de generelle konklusjonene som trekkes fra de kvalitative intervjuene våre med utvalgte husstander.

Grunnleggende må samfunnsvitenskapelige studier som sikter mot å belyse sammenhenger mellom utfall og mulige årsaksfaktorer (i motsetning til å måle utbredelsen av et fenomen på et gitt tidspunkt), betraktes som casestudier. Yin (1994:31, 36-37) understreker muligheten for å generalisere fra casestudier til teorier om de fenomenene som unders $\varnothing \mathrm{kes} \mathrm{i}$ de aktuelle casene. Undersøkelsen vår i Københavnregionen dreier seg om et problemfelt av generell interesse innenfor byplanlegging, nemlig sammenhengen mellem arealbruk og transport. Resultatene av Københavnundersøkelsen og andre tilsvarende casestudier kan sammenholdes med en teori om boliglokaliseringens betydning for transporten. Teorien vil fungere som en «sjablong» som de empiriske resultatene av casestudiene kan sammenlignes med (ibid:31). Yin betegner de generaliseringene som foretas på denne måten som analytiske generaliseringer, i motsetning til statistiske generaliseringer. Mulighetene for å generalisere de sammenhengene man har funnet i studier som Københavnundersøkelsen, ligger i casestudieforskningens analytiske generaliseringer, ikke i de «kontekstuavhengige» vitenskapenes statistiske generaliseringer.

En planlegger i Stockholm som ønsker å lokalisere ny boligbygging slik at transportomfanget begrenses, står da overfor spørsmålet om hvorvidt konteksten i Stockholmsregionen er tilstrekkelig lik situasjonen i Københavnområdet til at det er sannsynlig at sammenhengen mellom boliglokalisering og reiselengder også vil være til stede i Stockholmsregionen. Hvis tilsvarende resultater som i studiet av Københavnområdet også er funnet i Oslo, Bergen, Trondheim, Aarhus, Aalborg og Frederikshavn, vil konklusjonene framstå som mer overbevisende. I tråd med en «replikasjons-logikk» vil mulighetene for å generalisere til en bredere nordisk kontekst da være forbedret (Yin, 1994:45). Planleggeren vil da kunne konkludere med at det er overveiende sannsynlig at de perifere forstadsbeboere også i Stockholms byregion vil reise mer i dagliglivet enn beboerne i Stockholms indre deler.

Selv om respondentene hadde vært fullstendig representative for befolkningen, ville vi fortsatt stå overfor problemet med generalisering fra ett tidspunkt til et annet. Den praktiske bruken av undersøkelsesresultatene, f. eks. i kommunal planlegging, finner sted flere år etter at resultatene er publisert, og enda lengre tid etter datainnsamlingen. Planleggeren må derfor kvalitativt vurdere om den nåværende konteksten likner den originale konteksten nok til at konklusjonene kan benyttes i den aktuelle planleggingssituasjonen.

Muligheten for å forutsi på bakgrunn av en studie som undersøkelsen vår i Stor-København avhenger av en tilsvarende, kvalitativ generalisering i tid som når man vurderer den 
nåværende gyldigheten av resultatene fra en studie som er noen år gammel. Igjen er det nødvendig å gjøre en rekke vurderinger: Virker det rimelig å anta at situasjonen i framtiden vil være forskjellig på måter som gjør det sannsynlig at de nåværende sammenhengene mellom bystruktur og transport vil bli opphevet? I så fall, hvilke utviklingstrekk vil kunne lede til dette? Er det andre utviklingstrekk som drar i motsatt retning? Selv om det er umulig å gjøre helt sikre forutsigelser om strukturelle betingelsers påvirkninger på menneskers handlinger, særlig på lang sikt, kan noen antakelser virke rimeligere enn andre.

A kunne si noe om virkemidlers sannsynlige konsekvenser, er en nødvendig forutsetning for planlegging. Slike prediksjoner, basert på samfunnsvitenskapelig forskning, er også mulige. Det dreier seg imidlertid ikke om presise, kvantitative prediksjoner, men om kvalitative konsekvensvurderinger som begrenser seg til å si noe om påvirkningens retning og kanskje størrelsesorden. Det er heller ikke snakk om å forutsi framtidige begivenheter eller tilstander, men om forutsigelser av årsaksfaktorers virkninger. Mulighetene for forutsigelser gjelder dessuten ikke enkeltindividers handlinger, men hovedtendenser på aggregert nivå (innenfor en større befolkningsgruppe). De forutsigelsene jeg holder for mulige, er altså av den grove "tommelfingerregel"-typen, i motsetning til f. eks. framskrivning av trafikkvekst ved hjelp av matematiske simuleringsmodeller ${ }^{2}$, eller nytte-kostnads-analyser anvendt i byplanlegging.

Slike grove forhåndsvurderinger av sannsynlige konsekvenser er uunværlige hvis vi skal være i stand til å planlegge og utøve politikk for å oppnå en bedre samfunnsutvikling. Forskning om samfunnsmessige forhold, herunder om strukturers påvirkning på menneskers handlinger, kan bidra til å forbedre slike prediksjoner og dermed også forbedre mulighetene våre til å velge hensiktsmessige midler for å nå politiske mål.

\section{Sluttmerknader}

Kritisk realisme framstår som en velegnet vitenskapsteoretisk plattform for byplanforskning. Som det framgår av selve navnet, er kritisk realisme en realistisk vitenskapsteori som insisterer på at det finnes en virkelighet som eksisterer uavhengig av hvilke forestillinger vi måtte ha om den. Kritisk realisme mener også det er mulig å frambringe velbegrunnete antakelser om denne virkeligheten, selv om det vi betegner som kunnskap i prinsippet alltid er feilbarlig. Kritisk realisme anser at det er mulig å skjelne mellom troverdige og ikketroverdige utsagn om virkeligheten.

Kritisk realisme skiller seg her fra en rekke postmoderne og poststrukturalistiske retninger, f. eks. Rortys pragmatisme. А være opptatt av teorier og teoretisering i tradisjonell forstand er ifølge Rorty (1980) meningsløs aktivitet, siden teorier gir seg ut for å representere noe «der ute» - men det som er «der ute» kan man ifølge Rorty ikke si noe om. Rorty argumenterer, i likhet med mange andre postmoderne filosofer, for en radikal kontekstualisme, der bare det empiriske eksisterer, og der det empiriske er så mangefasettert og komplekst at det finnes et uendelig antall gyldige beskrivelser av virkeligheten. Vi kan derfor ifølge Rorty ikke si noe om virkeligheten i termer som sann og falsk.

En slik radikal kunnskapsrelativisme vil være ødeleggende for hele byplanleggingens idé. Hvis alle utsagn om virkeligheten er like gyldige, vil planleggerne f. eks. ikke ha noe grunnlag for å hevde at en bestemt løsning vil ha gunstigere konsekvenser i forhold til et gitt kriterium enn en hvilken som helst annen løsning. Planleggerne vil da stå uten muligheter for på faglig grunnlag å imøtegå utsagn f. eks. fra en byggherre som ønsker å etablere et stort kjøpesenter ved en av motorveiene i utkanten av byen, og som hevder at dette ikke vil føre til nevneverdig mer biltrafikk. Ved å avvise planleggernes bruk av vitenskapelig kunnskap om sammenhenger mellom mål og midler og om konsekvenser av handlingsalternativer, fjerner man planleggernes viktigste politiske ressurser i diskusjon med andre aktører. 
Kritisk realisme distanserer seg samtidig fra positivismens nedvurdering av kunnskap basert på forskning der observasjonene ikke egner seg til matematisk måling og analyse. Byplanlegging omfatter en rekke forhold som er vanskelige eller umulige å måle og som i hvert fall ikke kan kvantifiseres presist, og som dessuten er kontekstavhengige. Positivismen har en tendens til å betrakte teorier om slike årsaksfaktorer eller konsekvenser som uvitenskapelige og karakterisere dem som rent subjektive meninger. Eller man ser bort fra kontekstavhengigheten og lager beregninger som om regresjonskoeffisienter og elastisiteter funnet i én by på ett tidspunkt også kan settes inn i regnestykker i andre byer og på andre tidspunkter.

Kritisk realisme peker seg særlig ut som en velegnet plattform for byplanforskning og byplanleggingspraksis fordi:

- Kritisk realisme ikke bare tillater tverrfaglighet, men anser tverrfaglig integrasjon som nødvendig, siden virkeligheten består av mer eller mindre åpne systemer der konkrete begivenheter er resultatene av samspillet av en rekke ulike årsaksmekanismer som typisk hører til ulike disipliners forskningsfelt.

- Kritisk realisme anerkjenner både aktørers og strukturers selvstendige kausale påvirkningskrefter. Selv om de bygde omgivelsene så vel som ikke-materielle samfunnsstrukturer er sosialt konstruert, er vi i enhver konkret situasjon under påvirkning fra eksisterende strukturer (som riktignok senere kan bli endret av aktører). Denne virkelighetsoppfatningen gir en god plattform for å unders $\varnothing \mathrm{ke}$ årsakssammenhenger mellom samfunnsforhold, romlige bystrukturer og aktørers (herunder planleggernes) handlinger.

- Kritisk realisme avviser positivismens tese om symmetri mellom forklaring og prediksjon og troen på presise, kvantitative prediksjoner basert på universelle sammenhenger mellom variabler. Kvalitative vurderinger av virkemidlers sannsynlige konsekvenser anses imidlertid som mulige, eventuelt også med forsiktige, konteksttilpassete anslag om effektenes størrelsesorden. Den typen forutsigelser som kritisk realisme anser som forsvarlige, passer godt med slike vurderinger som byplanleggere typisk foretar av ulike arealbruksalternativer, men står i skarp kontrast til nytte-kostnadsmetoden og måten modellbaserte trafikkprognoser vanligvis blir benyttet på i transportplanlegging.

\author{
Petter Næss \\ Professor \\ Universitetet for miljø- og biovitenskap UMB, Institutt for landskapsplanlegging \\ e-post: petter.nass@umb.no
}




\section{Litteraturreferanser}

Archer, M. S. (2000) Being Human. The Problem of Agency. Cambridge: Cambridge University Press.

Benton, T. (2001) Why are sociologists naturephobes? In Lopez, J \& Potter, G. (eds): After Postmodernism: An Introduction to Critical Realism, pp. 132-145. London/New York: Athlone Press.

Bhaskar, R. (1993) Dialectic - the Pulse of Freedom. London: Routledge.

Bhaskar, R. (1998) The Possibility of Naturalism. A Philosophical Critique of the Contemporary Human Sciences. Third Edition. (Første utgave publisert i 1979.) London/New York: Routledge.

Bhaskar, R. (2008) A Realist Theory of Science - with a new introduction. London/New York: Routledge. (Første utgave publisert i 1975.)

Bhaskar, R. \& Danermark, B. (2006) Metatheory, interdisciplinarity and disability research: a critical realist perspective, Scandinavian Journal of Disability Research, 8, pp. 278-297.

Bransen, J. (2001) Verstehen and erklären, philosophy of, i Smelser, N.J., \& Baltes, P.B. (eds.): International Encyclopedia of the Social and Behavioral Sciences. Oxford: Elsevier Science.

Brox, O. (1989) Praktisk samfunnsvitenskap. Oslo: Universitetsforlaget.

Buch-Hansen, H. \& Nielsen, P. (2005) Kritisk realisme. Frederiksberg: Roskilde Universitetsforlag.

Castells, M. (1977) The Urban Question: a Marxist Approach. London: Arnold.

Danermark, B.; Ekström, M.; Jacobsen, L. \& Karlsson, J. C. (2001) Explaining Society. Critical realism in the social sciences. London/New York: Routledge.

Dunlap, R. E. and Catton, W. R. jr. (1983) What environmental sociologists have in common (whether concerned with 'built' or 'natural' environments), Sociological Inquiry, 53, pp. 113-135.

Giddens, A. (1984) The Constitution of Society. Outline of a Theory of Structuration. Cambidge: Polity Press.

Høyer, K. G. \& Næss, P. (2008) Interdisciplinarity, Ecology and Scientific Theory - The Case of Sustainable Urban Development, Journal of Critical Realism, 7, pp. 5-33

Karlsson, J. C. (2009) Delvis öppna och delvis slutna system. En självkritisk betraktelse, i En realistisk sociologi i praktiken. Nio texter om samhället, red. Bengtsson, M, Daoud, A. \& Seldén, D., pp. 33-49. Göteborg: Göteborgs Universitet, Sociologiska Institutionen.

Landau, R. (1984) British Architecture: A Historiography of the Current Discourse, UIA - International Architect 5. London.

Lawson, T. (1997) Economics and Reality. London/New York: Routledge.

Lidskog, R. (1998) Society, Space and Environment. Towards a Sociological Re-conceptualisation of Nature, Scandinavian Housing \& Planning Research, 15, pp. 19-35.

Lincoln, Y. \& Guba, E. (1985) Naturalistic Inquiry. Beverly Hills, Ca: Russell Sage.

Needham, B. (2000) Spatial planning as a design discipline: a paradigm for Western Europe? Environment and Planning B: Planning and Design, 27, pp. 437 - 453.

Næss, P. (2004) Prediction, Regressions and Critical Realism, Journal of Critical Realism, 3, pp. $133-164$.

Næss, P. (2005) Residential Location Affects Travel Behavior - But How and Why? The case of Copenhagen Metropolitan Area, Progress in Planning, 63, pp. 167-257.

Næss, P. (2008) Rom i planleggingsperspektiv, FORMakademisk, 1, s. 45-57.

Næss, P. (2009) Residential Self-Selection and Appropriate Control Variables in Land Use-Travel Studies, Transport Reviews, 29, pp. 293-324.

Næss, P. (2013) Residential location, transport rationales and daily-life travel behavior: The case of Hangzhou Metropolitan Area, China. Publiseres i Progress in Planning, 79(1), januar 2013.

Næss, P. \& Saglie, I. L. (2000) Surviving between the trenches: Planning research, methodology and theory of science, European Planning Studies, 8, pp. 729-750.

Næss, P. \& Strand, A. (2012) What kinds of traffic forecasts are possible? Journal of Critical Realism, 11, pp. 277-295. 
Rorty, R. (1980) Philosophy and the Mirror of Nature. Princeton: Princeton University Press

Sayer, A. (1992) Method in Social Science. A Realist approach, 2. Edition. London: Routledge.

Sayer, A. (2000) Realism and Social Science. London/Thousand Oaks/New Delhi: Sage Publications.

Skogheim, R. (2008) Mellom kunsten og kundene. Arkitekters yrkessosialisering og profesjonelle praksis.

Doktoravhandlinger forsvart ved Det samfunnsvitenskapelige fakultet, Universitetet i Oslo. No. 120.

Strand, A. (1991) Vedlegg til forslag til forskningsprogram om kommunal planlegging. Oslo: Nasjonal komité for miljøvernforskning/NAVF.

Thomsen, J. F. (2000) Magt og indflydelse. Aarhus: Århus Universitet/Magtudredningen.

Tonboe, J. (1993) Rummets sociologi. Kritik af teoretiseringen af den materielle omverdens betydning i den sociologiske og kulturgeografiske tradition. København: Akademisk forlag.

Yin, R. (1994) Case Study Research: Design and Methods. Second Edition. Series: Applied Social Research Methods, 5. Thousand Oaks/London/New Delhi: Sage Publications.

\footnotetext{
${ }^{1}$ Gjennom såkalte multivariate regresjonsanalyser utførte vi statistisk kontroll for en lang rekke demografiske, sosioøkonomiske og holdningsmessige variabler. Individenes transportatferd påvirkes imidlertid opplagt også av en rekke andre faktorer som ikke inngikk i analysene. Spørsmålet er derfor om disse ikke-kontrollerte faktorene varierer tilfeldig, eller skaper systematiske skjevheter som gjør at sammenhengene ville ha vært annerledes hvis vi hadde vært i stand til å korrigere for virkningene av alle disse ukjente faktorene.
}

${ }^{2}$ Næss \& Strand (2012) diskuterer, ut fra et kritisk-realistisk perspektiv, hva slags trafikkfremskrivninger det er mulig å lage og hvilke typer trafikkfremskrivninger som ikke kan lages med rimelig grad av nøyaktighet. I stedet for å forsøke å beregne hvordan den generelle trafikkutviklingen på landsbasis vil bli, foreslår vi å erstatte slike modellberegninger med scenarioanalyser av ulike forløp. For å vurdere trafikkonsekvensene av å bygge versus ikke bygge et foreslått projekt, foreslår vi å benytte teoriinformerte, hovedsakelig kvalitative analyser, supplert med enkle beregninger basert på erfaringstall for den trafikkskapende effekten av kapasitetsutvidelser, fortolket og tilpasset i forhold til den lokale konteksten. Tradisjonelle trafikkmodellberegninger bør bare benyttes for å skjelne mellom ulike linjeføringer for et prosjekt innenfor en gitt transportkorridor, eller endringer av trafikkfordelingen innenfor et begrenset lokalt veinett som følge av tiltak som ikke endrer den totale trafikkmengden i området. 